\title{
Development of Life Skills Through Physical Education and Sports
}

\author{
I Kadek Suardika ${ }^{1, *}$ Amung Ma'mun ${ }^{2,}$ Nurlan Kusmaedi ${ }^{3,}$ Dian Budiana ${ }^{4}$ \\ ${ }^{I}$ Doctoral Program of Sports Education, School Postgraduates Studies, Universitas Pendidikan Indonesia, Indonesia \\ ${ }^{2,3,4}$ School Postgraduates Studies, Universitas Pendidikan Indonesia, Indonesia \\ *Corresponding author. Email: ikadeksuardika@upi.edu
}

\begin{abstract}
This study aims to determine the impact of physical education on high school students' life skills. The research method used is an experimental research design with one group pretest-posttest design. The number of samples was 51 people divided into three groups - sampling using the purposive sampling technique. Instruments to measure life skills using a questionnaire, a scale of life skills in sports. Based on the data processing and analysis results, the following conclusions can be drawn: There are differences in the development of life skills between students who are given life skills and students who are not given life skills. There is also a difference in life skills development between students who are given a load of life skills and students who do not carry out physical education activities. From the study results, it can be concluded that the development of life skills of students who take part in physical education activities that are given a load of life skills is better than students who take part in physical education activities without being given a charge of life skills. The development of student life skills can be implemented in everyday life to face the needs and challenges of life in the future.
\end{abstract}

Keywords: Physical education and sports, Life skills.

\section{INTRODUCTION}

Through physical education, teachers must help students develop themselves, especially developing personality and being able to interact well. It is not only participation in the sport that can promote positive development but the individual's experience in the sport that may be an essential factor in positive development [1]. Through physical education, teachers must help students develop themselves, especially developing personality and being able to interact well. It is not only participation in the sport that can promote positive development but the individual's experience in the sport that may be an essential factor in positive development [2].

Schools must have goals that prepare students for their lives, successfully engage in good relationships with fellow students, and have experienced while at school [3]. According to [4] revealed life skills have been defined as physical, behavioral, and cognitive abilities that enable adolescents to succeed in a different environment in which they live. In addition, researchers have begun to develop a framework on which to base the development of exercise programs that facilitate positive adolescent development [5]. Several recent studies have been conducted to identify the most significant life skills needs of young people involved in sports. For example, a survey of high school coaches showed [6] that failure to take responsibility for self and others, poor communication and listening skills, lack of motivation, and work ethic were the three areas where youth most needed to thrive.

Life skills (life skills) as a skill that allows individuals to succeed in different environments where they live, such as school, home, and their environment [1]. Meanwhile, [7] states that "such life skills are defined as skills needed to deal with the demands and demands of everyday life." Life skills as internal personal assets, characteristics, and skills such as goal setting, emotional control, self-esteem, and a hard work ethic can be facilitated or developed in sports and transferred for use in non-sporting circumstances. The concept of positive youth development is broader than life skills development and includes life skills development. All life skills focus on positive adolescent development; not all positive adolescent development efforts focus on developing life skills [6]. 


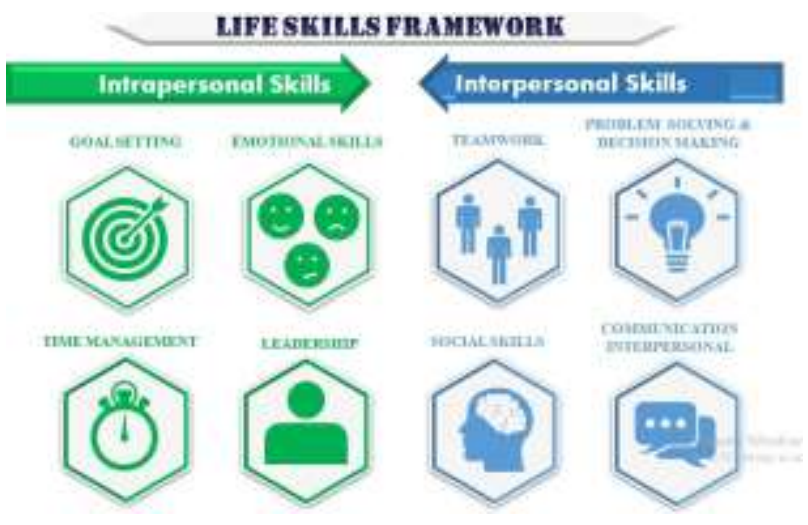

Figure 1 Life skills framework

Numerous studies have shown that youth develop a range of life skills through exercise [8], [9], [10]. In line with [2], we view life skills as behavioral, cognitive, interpersonal, and intrapersonal competencies that can be learned, developed, and perfected. Using the Life Skills Scale for Sport (LSSS), researchers were able to investigate the eight most frequently cited life skills intended by youth to be developed through sports (Figure 1), such as timework, goal setting, time management, leadership, social skills, interpersonal communication, emotional skills, and problem-solving $\&$ decision making [7]. This scale provides researchers with a measure to comprehensively assess the eight life skills, with this scale making it easier to measure the development of life skills in sports.

It is citing the framework (Figure 1) of [11] that life skills are classified as intrapersonal skills (i.e., skills that are more internal, such as goal setting) or intrapersonal skills (i.e., skills that are useful during social interactions, such as teamwork). Furthermore, each life skill is assigned an icon to represent that skill visually.

\section{METHODS}

\subsection{Participants}

The population in this study were students of class $\mathrm{X}$ SMA Negeri 1 Busungbiu, amounting to 250 students. The sample in this study was class $\mathrm{X}$ students, amounting to 51 people for the regular class. The technique used in this sampling is to use a purposive sampling technique. Purposive sampling is a sampling technique with specific considerations (Sugiyono, 2012, p. 124).

\subsection{Procedures}

Before the treatment was carried out, all youths did a pretest filling out the Sports Life Skills Scale questionnaire, which was available for 45 minutes. After the pretest was conducted, the child followed the treatment according to their group for twelve meetings. After the treatment was completed, the youths did a posttest to complete the filling of the questionnaire that was already available for 45 minutes.

\subsection{Data Analysis}

\subsubsection{First Hypothesis Test}

After doing the prerequisite test, then the Hypothesis test can be done. Furthermore, to test the data with oneway Anova (Anova One Way) to determine whether there are differences between groups. There is a real difference in the development of Life skills between the physical education group that is given Life Skills content, the physical education group that is not given Life Skills range, and the nonphysical education group without Life Skills content.

The results of testing the research hypothesis can be seen in Table 1 as follows:

Table 1. ANOVA one way test

\begin{tabular}{|c|c|c|c|c|c|c|}
\hline & & $\begin{array}{l}\text { Sum of } \\
\text { Squares } \\
\end{array}$ & Df & $\begin{array}{c}\text { Mean } \\
\text { Square } \\
\end{array}$ & $\mathrm{F}$ & Sig. \\
\hline \multirow{3}{*}{$\begin{array}{l}\text { Life } \\
\text { Skills }\end{array}$} & \multirow{2}{*}{$\begin{array}{l}\text { Between } \\
\text { Groups } \\
\text { Within } \\
\text { Groups } \\
\end{array}$} & 1469.733 & 2 & 734.867 & 79.566 & .000 \\
\hline & & 526.450 & 57 & 9.236 & & \\
\hline & Total & 1996.183 & 59 & & & \\
\hline
\end{tabular}

From the above data obtained, F Count 79.566 and F table $1, \mathrm{H} 0$ is rejected, and $\mathrm{H} 1$ is accepted. There are differences in the development of Life Skills between the physical education group with Life Skills content, the physical education group without Life Skills content, and the nonphysical education group without Life Skills content. So it can be concluded that the training program, if integrated with the Life Skills program, has a significant difference with the physical education group without Life Skills content and the nonphysical education group without Life Skills content.

\subsubsection{Second Hypothesis Test}

Table 2. Life skills development level of groups A and B

\begin{tabular}{|c|l|c|c|c|c|}
\hline \multicolumn{1}{|c|}{ Group } & N & Mean & $\begin{array}{c}\text { Std. } \\
\text { Deviation }\end{array}$ & $\begin{array}{c}\text { Std. } \\
\text { Error } \\
\text { Mean }\end{array}$ \\
\hline Life Skills & $\begin{array}{l}\text { (A) physical } \\
\text { education with } \\
\text { life skills }\end{array}$ & 20 & 146.05 & 2.704 & 0.605 \\
\cline { 2 - 6 } & $\begin{array}{l}\text { (B) physical } \\
\text { education } \\
\text { without life skills }\end{array}$ & 20 & 139.35 & 3.422 & 0.765 \\
\hline
\end{tabular}

From table 2, there is an average value (mean) for group A of 146.05, which is higher than group B of 139.35 with an average difference of 6.700 . Thus, it can be concluded that the physical education group that was given Life Skills content had higher Life Skills 
development compared to the physical education group without Life Skills content.

\subsubsection{Third Hypothesis}

Table 3. Life skills development level of groups A and $\mathrm{C}$

\begin{tabular}{|l|l|l|l|l|l|}
\hline \multicolumn{1}{|c|}{ Group } & $\mathrm{N}$ & Mean & $\begin{array}{c}\text { Std. } \\
\text { Deviation }\end{array}$ & $\begin{array}{c}\text { Std. } \\
\text { Error } \\
\text { Mean }\end{array}$ \\
\hline $\begin{array}{l}\text { Life } \\
\text { Skills }\end{array}$ & $\begin{array}{l}\text { (A) physical } \\
\text { education with } \\
\text { life skills }\end{array}$ & 20 & 146.05 & 2.704 & 0.605 \\
\cline { 2 - 6 } & $\begin{array}{l}\text { (C) non } \\
\text { physical } \\
\text { education } \\
\text { without } \\
\text { life skills }\end{array}$ & 20 & 133.95 & 2.946 & 0.659 \\
\hline
\end{tabular}

The results of the data in table 3 show that the average value (mean) of the physical education group that is given Life Skills content is 146.05 higher than the nonphysical education group without Life Skills content with an average of 133.9. With the results of these calculations, it can be concluded that the physical education group given the Life Skills range had higher Life Skills development than the nonphysical education group without Life Skills content.

\subsubsection{Fourth Hypothesis}

Table 4. Life skills development level of groups B and $\mathrm{C}$

\begin{tabular}{|l|l|l|l|l|l|}
\hline \multicolumn{1}{|c|}{ Group } & $\mathrm{N}$ & Mean & $\begin{array}{c}\text { Std. } \\
\text { Deviation }\end{array}$ & $\begin{array}{c}\text { Std. } \\
\text { Error } \\
\text { Mean }\end{array}$ \\
\hline Life_skills & $\begin{array}{l}\text { (B) physical } \\
\text { education } \\
\text { without life } \\
\text { skills }\end{array}$ & 20 & 139.35 & 2.704 & 0.605 \\
\cline { 2 - 6 } & $\begin{array}{l}\text { (C) non physical } \\
\text { education } \\
\text { without } \\
\text { life skills }\end{array}$ & 20 & 133.95 & 3.422 & 0.765 \\
\hline
\end{tabular}

The data results in table 4 show that the average value (mean) of the physical education group without being given Life Skills content is 139.35 higher than the nonphysical education group without Life Skills content with an average of 133.9. With the results of these calculations, it can be concluded that the physical education group without being given a Lifeskills load has a higher Life Skills development compared to the nonphysical education group without being given a Life skill.

\section{RESULTS AND DISCUSSION}

A new experience for the physical education group that is integrated with the Life Skills program is that the training program, in addition to focusing on physical performance, then provides lessons on how other aspects (Life Skills) are essential in achieving good physical performance in the training process, namely: how athletes learn to manage their time. Activities (time management) because a teenage athlete is a student who also has activities in the school environment and arranges vacation time because of the hectic activities of 6 days a week; of course, it can create a sense of saturation. Then goal-setting skills, how athletes start planning the process. This is certainly a new thing among sports in integrating Life Skills into training programs for athletes. With the Life Skills program, athletes are participating in sports for the sport itself and how athletes can increase their capacity to develop their potential in sport and their skills. And if sports achievement is measured, only the first to third place winners will get a certificate or medal. Still, it is different if the benchmark for athlete improvement is the development of Life Skills as personal assets for their future provision. All athletes have the same opportunity to get an increase in Life Skills development. Life Skills teaching comes as a counterweight to a student's dual career-physical education to manage multiple career roles. Dealing with daily routines means elite athletes have to adapt to the part of an athlete. Elite athletes must develop their strategies, such as being independent and managing limited time [20]. So time management skills, goal setting, including one component of Life Skills, should be taught in training programs [13]. The balance of time as a student and the demands of practice and rest time must be balanced. So the training program integrated with Life Skills can encourage adolescents to increase academic success as students and performance as physical education [21].

\section{CONCLUSION}

This study resulted in several conclusions that can be drawn. Namely, the Lifeskills component should be integrated in a structured and deliberate manner into the training program because it has a dominant influence on adolescent athletes to get positive experiences. This is indicated by the results of the study that: first, there are significant differences in the development of Life Skills between the physical education group that was given Life Skills content, the physical education group that was not given Life Skills range, and the nonphysical education group without Life Skills content. Second, the physical education group given Life Skills content had a higher development rate than the group of athletes who were not given Life Skills range. Third, the physical education group given Life Skills content had higher development than the nonphysical education group without life skills. Fourth, the physical education group without being given Life Skills content was more developed than the nonphysical education group without being given Life Skills. 
Thus, sport is an ideal vehicle for developing Life skills by integrating a systematic and structured training process. In situations like this, athletes learn and apply Life skills components in the training process to be used in everyday life when doing personal tasks. Furthermore, athletes realize that the impact of participating in sports activities is met with many other people, and they must be able to adapt, both with other people and with the atmosphere of sports training. Besides that, the most important thing is that these young athletes get positive experiences, especially about how they get to know Life Skills through the sports training process. In another sense, they become convinced that sport is related to learning skills to achieve achievement and becomes a process for selfdevelopment that allows them to succeed in facing life into adulthood. Specifically, it was successfully revealed that their experience was getting used to the training program's target or time and load. Many targets were applied by the trainer through training hours, training load. This has become an awareness of physical education so that positive habits grow and develop in other lives by applying the principles contained in Life Skills obtained through training that is used intentionally, structured, and systematically so that athletes can realize and apply them.

\section{ACKNOWLEDGMENTS}

Acknowledgements are given to Sports Education, Graduate School, Universitas Pendidikan Indonesia. In addition, we would like to thank the experts in our study who provided written informed consent.

\section{REFERENCES}

[1] S. Danish, T. Forneris, K. Hodge, and I. Heke, "Enhancing youth development through sport," World Leis. J., vol. 46, no. 3, pp. 38-49, 2004, DOI: $10.1080 / 04419057.2004 .9674365$.

[2] S. J. Danish, T. Forneris, and I. Wallace, "Sportbased life skills programming in the schools," $J$. Appl. Sch. Psychol., vol. 21, no. 2, pp. 41-62, 2005, DOI: 10.1300/J370v21n02_04.

[3] R. Bailey, "Sport, physical education and educational worth," Educ. Rev., vol. 70, no. 1, pp. 51-66, 2018, DOI: 10.1080/00131911.2018.1403208.

[4] C. Bean and T. Forneris, "Examining the Importance of Intentionally Structuring the Youth Sport Context to Facilitate Positive Youth Development," vol. 3200, no. June, pp. 0-16, 2016, DOI: 10.1080/10413200.2016.1164764.

[5] T. Forneris, M. Camiré, and P. Trudel, "International Journal of Sport and The development of life skills and values in high school sport: Is there a gap between stakeholder ' $\mathrm{s}$ expectations and perceived experiences ?" no. October 2014, pp. 37-41, DOI: 10.1080/1612197X.2012.645128.
[6] D. Gould and S. Carson, "Life skills development through sport: current status and future directions," Int. Rev. Sports Exerc. Psychol., 2008, DOI: 10.1080/17509840701834573.

[7] L. D. Cronin and J. Allen, "Development and initial validation of the Life Skills Scale for Sport," Psychol. Sports Exerc., vol. 28, pp. 105119 2017 ,

DOI:

10.1016/j.psychsport.2016.11.001.

[8] R. Rohmanasari, A. Ma'mun, and T. Muhtar, "Dampak Kegiatan Ekstrakurikuler terhadap Perkembangan," J. Penelit. Pendidik., vol. 18, no. 3, pp. 371-382, 2018.

[9] C. Trottier and S. Robitaille, "Fostering Life Skills Development in High School and Community Sport: A Comparative Analysis of the Coach ' s Role," no. 2000, pp. 10-21, 2014.

[10] M. A. Whitley, E. M. Wright, and D. Gould, "Journal of Sport for Development Coaches ' Perspectives on Sport-Plus Programmes for Underserved Youth: An Exploratory Study in South Africa," vol. 1, no. 2, 2013.

[11] K. Kendall, M. Camiré, C. N. Bean, and T. Forneris, "Integrating life skills into Golf Canada ' s youth programs: Insights into a successful research to practice partnership," vol. 0704, no. September 2016, DOI: 10.1080/21520704.2016.1205699.

[12] J. R. Fraenkel, N. E. Wallen, and H. H. Hyun, How to Design and Evaluate Research in Education T, Eighth Edi. New York, Americas: The McGrawHill Companies, 2012.

[13] L. Cronin et al., "Life skills development in physical education: A self-determination theorybased investigation across the school term," Psychol. Sports Exerc., vol. 49, no. May, p 101711, 2020, doi: 10.1016/j.psychsport.2020.101711.

[14] R. W. Larson, D. M. Hansen, and G. Moneta, "Differing profiles of developmental experiences across types of organized youth activities," Dev. Psychol., vol. 42, no. 5, pp. 849-863, 2006, DOI: 10.1037/0012-1649.42.5.849.

[15] D. M. Hansen, R. W. Larson, and J. B. Dworkin, "What adolescents learn in organized youth activities," J. Res. Adolesc., vol. 13, no. 1, pp. 25$55,2003$.

[16] D. Gould and S. Carson, "The relationship between perceived coaching behaviors and developmental benefits of high school sports participation," Hellenic Journal of Psychology. 2010.

[17] A. Ma'am, "Development of the Educational Sport in Indonesia: The Policy Study Based on the Law of National Sports System," vol. 5, no. 1, pp. 3348, 2015.

[18] M. Camiré, P. Trudel, and T. Forneris, "Examining how model youth sport coaches learn to facilitate positive youth development," Phys. Educ. Sport 
Pedagog., vol. 19, no. 1, pp. 1-17, 2014, doi: 10.1080/17408989.2012.726975.

[19] F. de S. F. dos Santos, M. Camiré, and P. H. da F. Campos, "Youth sports coaches' role in facilitating positive youth development in Portuguese field hockey," Int. J. Sport Exerc. Psychol., vol. 16, no. 3, pp. 221-234, 2018, DOI: 10.1080/1612197X.2016.1187655.

[20] G. Khalili Moghaddam and C. R. Lowe, "Physical activity," in SpringerBriefs in Applied Sciences and Technology, 2019.

[21] L. Cronin, "Life Skills Development Through Youth Sport: Antecedents, Consequences, and Measurement," 2015. 